\title{
Antimicrobial Activity of the Origanum vulgare $L$. Essential Oil Against Pathogenic and Starter Bacteria Species Related To Brazilian Semi-Hard Cheese (Coalho)
}

Geany Targino de Souza (I), Rayssa Julliane de Carvalho (I), Neyrijane Targino de Souza (I), Jessica Bezerra dos Santos Rodrigues (I), Danilo Elias Xavier (I), Evandro Leite de Souza (I), Marciane Magnani (I)

(I) UFPB - Federal University of Paraíba (Cidade Universitária, s/n - 58051-900 - Castelo Branco, João Pessoa - PB, Brazil)

\section{Resumo}

Coalho cheese is a semi-hard cheese with medium to high moisture that is obtained by a simple manufacture process usually using commercial coagulating agent and starter of the mesophilic lactic cultures Lactococcus lactis subsp. cremoris and L. lactis subsp. lactis. However, the physicochemical characteristics of this dairy product may favor the survival and growth of the pathogenic bacteria frequently associated to foodborne diseases. The current trend of a negative consumer perception of chemical preservatives increases the interest in use of essential oils, particularly which obtained from Origanum vulgare L. (OVEO), as antimicrobial compounds for food preservation. However there is a lack of information regarding the effects of this oil against starter cultures. This study assessed the activity of OVEO against the mesophilic lactic cultures (L. lactis subsp. cremoris and L. lactis subsp. lactis - Chr. Hansen Brazil@) used as starter in manufacture of coalho cheese and against Staphylococcus aureus ATCC 6538 and Listeria monocytogenes ATCC 7644 strains. The minimum inhibitory concentration (MIC) was performed by microdilution in broth assays using OVEO (Ferquima ${ }^{\circledR}$ Ltda) concentrations from 0.3 to 40 $\mu \mathrm{L} / \mathrm{mL}$, according procedures preconized by Clinical and Laboratory

\footnotetext{
Referência:

Geany Targino de Souza, Rayssa Julliane de Carvalho, Neyrijane Targino de Souza, Jessica Bezerra dos Santos Rodrigues, Danilo Elias Xavier, Evandro Leite de Souza, Marciane Magnani. Antimicrobial Activity of the Origanum vulgare L. Essential Oil Against Pathogenic and Starter Bacteria Species Related To Brazilian Semi-Hard Cheese (Coalho). In: Anais do 12 Congresso Latinoamericano de Microbiologia e Higiene de Alimentos - MICROAL 2014 [= Blucher Food Science Proceedings, num.1, vol.1]. São Paulo: Editora Blucher, 2014. DOI 10.5151/foodsci-microal-325
} 
Standards Institute. All bacterial suspensions were standardized $\left(10^{8}\right)$ and tested in single and mixed cultures (1:1) for S. aureus or L. monocytogenes and in a mixed culture $(1: 1)$ for lactic starter strains. MIC values of OVEO for $\mathrm{S}$. aureus and L. monocytogenes were $2.5 \mu \mathrm{L} / \mathrm{mL}$ in single culture, while for mixed culture lower MIC value was observed $(1.25 \mu \mathrm{L} / \mathrm{mL})$. In assays with the mixed culture of L. lactis subsp. cremoris and L. lactis subsp. lactis. OVEO showed MIC value of $0.60 \mu \mathrm{L} / \mathrm{mL}$. The results suggest the OVEO as an interesting approach to inhibit pathogens frequently associated to coalho cheese, however the inhibitory effects against starter lactic culture need be considered for the application of OVEO in this product.

Palavras-Chave: Coalho cheese, Essential oil, Lactic cultures, Mixed cultures, Oregano

Agência de Fomento: 